\title{
Millennial meridional dynamics of the Indo-Pacific Warm Pool during the last termination
}

\author{
L. Lo ${ }^{1}$, C.-C. Shen ${ }^{1}$, K.-Y. Wei ${ }^{1}$, G. S. Burr ${ }^{1,2}$, H.-S. Mii ${ }^{3}$, M.-T. Chen ${ }^{4}$, S.-Y. Lee ${ }^{5}$, and M.-C. Tsai ${ }^{1}$ \\ ${ }^{1}$ High-Precision Mass Spectrometry and Environment Change Laboratory (HISPEC), Department of Geosciences, National \\ Taiwan University, Taipei 10617, Taiwan ROC \\ ${ }^{2}$ NSF-Arizona Accelerator Mass Spectrometry Facility, Department of Physics, University of Arizona, Tucson, AZ 85721, \\ USA \\ ${ }^{3}$ Department of Earth Sciences, National Taiwan Normal University, Taipei 11677, Taiwan ROC \\ ${ }^{4}$ Institute of Applied Geosciences, National Taiwan Ocean University, Keelung 20224, Taiwan ROC \\ ${ }^{5}$ Research Center for Environmental Changes, Academia Sinica, Taipei 11529, Taiwan ROC
}

Correspondence to: C.-C. Shen (river@ntu.edu.tw)

Received: 5 July 2014 - Published in Clim. Past Discuss.: 21 August 2014

Revised: 30 November 2014 - Accepted: 3 December 2014 - Published: 23 December 2014

\begin{abstract}
To develop an in-depth understanding of the natural dynamics of the Indo-Pacific Warm Pool (IPWP) during the last deglaciation, stacked north- (N-) and southIPWP (S-IPWP) thermal and hydrological records over the past 23-10.5 ka were built using planktonic foraminiferal geochemistry data from a new core, MD05-2925 $\left(9.3^{\circ} \mathrm{S}\right.$, $151.5^{\circ} \mathrm{E}$, water depth $1661 \mathrm{~m}$ ) in the Solomon Sea and eleven previous sites. Ice-volume-corrected seawater $\delta^{18} \mathrm{O}$ $\left(\delta^{18} \mathrm{O}_{\mathrm{SW}-\mathrm{IVC}}\right)$ stacks show that S-IPWP $\delta^{18} \mathrm{O}_{\mathrm{SW}-\mathrm{IVC}}$ values are indistinguishable from their northern counterparts through glacial time. The N-IPWP SST (sea surface temperature) stacked record features an increasing trend of $0.5^{\circ} \mathrm{C} \mathrm{ka}^{-1}$ since $18 \mathrm{ka}$. Its S-IPWP counterpart shows an earlier onset of temperature increase at $19 \mathrm{ka}$ and a strong teleconnection to high-latitude climate in the Southern Hemisphere. Meridional SST gradients between the $\mathrm{N}$ - and SIPWP were $1-1.5^{\circ} \mathrm{C}$ during the Bølling/Allerød period and $1^{\circ} \mathrm{C}$ during both Heinrich event 1 and the Younger Dryas, due to a warmer S-IPWP. A warm S-IPWP during the cold events could weaken the southern hemispheric branch of the Hadley cell and reduce precipitation in the Asian monsoon region.
\end{abstract}

\section{Introduction}

The Indo-Pacific Warm Pool (IPWP) is the largest warm water mass in the world, with an annual average sea surface temperature (SST) greater than $28^{\circ} \mathrm{C}$ (Yan et al., 1992). Vigorous regional atmospheric circulation transports latent heat and water moisture from the IPWP to the middle and high latitudes (Yan et al., 1992). For the past 5 decades, the IPWP has experienced surface water freshening and a westward shift in precipitation, resulting in regional drought in eastern Africa and storm track changes in eastern Australia (Cravatte et al., 2009; Williams and Funk, 2011). Since the early 2000s, intensive paleoclimatological studies have been conducted in this region to understand long-term thermal and hydrological changes in the IPWP. These studies have shed light on the influence of glacial/interglacial (G/IG) cycles and have placed constraints on the relationships between (1) warm pool thermal and hydrological fluctuations, (2) high-latitude ice sheets, and (3) greenhouse gas concentrations during the late Pleistocene (e.g., Lea et al., 2000; Stott et al., 2002, 2004; Visser et al., 2003; Rosenthal et al., 2003; de GaridelThoron et al., 2005; Steinke et al., 2006; Levi et al., 2007; Xu et al., 2008; Linsley et al., 2010; Bolliet et al., 2011; Mohtadi et al., 2014).

Stacked IPWP SST and seawater oxygen isotope $\left(\delta^{18} \mathrm{O}_{\mathrm{SW}}\right)$ records from the last glacial to the Holocene show a close link among the IPWP SST, the Asian-Australian 
Sea surface temperature

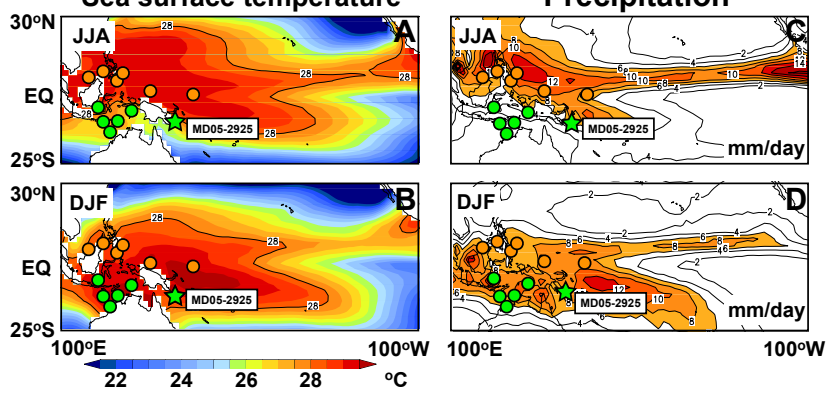

Figure 1. Climatological map of the IPWP SST (left) and precipitation (right) during AD 1950-2004 (Reynolds et al., 2002). Upper panels are June-July-August (JJA), and lower panels are DecemberJanuary-February (DJF) averages of (a, c) SSTs and (b, d) precipitation distribution maps. SST and precipitation are at $0.5^{\circ} \mathrm{C}$ and $2 \mathrm{~mm}$ day $^{-1}$ intervals. Our study site MD05-2925 is shown as the green star. Orange and green dots denote previous study sites in the IPWP region (Table 2) for reconstruction of meridional thermal and precipitation variations during the glacial/interglacial change.

monsoon (AAM) system, and sea level (Stott et al., 2004; Oppo et al., 2009; Linsley et al., 2010). However, a complicated ocean-island configuration and regional topography hinder the use of these records to describe past climate changes in detail (Griffiths et al., 2009; Mohtadi et al., 2011). In particular, little is known about the meridional thermalhydrological dynamics between the N (north)-IPWP and S (south)-IPWP during the last termination.

Here we present new oceanic proxy-inferred SST and ice-volume-corrected surface seawater oxygen isotope $\delta^{18} \mathrm{O}$ $\left(\delta^{18} \mathrm{O}_{\mathrm{SW}-\mathrm{IVC}}\right)$ records from the Solomon Sea, Papua New Guinea (PNG), for the past 23-10.5 ka (before AD 1950, hereafter). New SST and $\delta^{18} \mathrm{O}_{\text {SW-IVC }}$ stacked records since the last termination are built for both the N- and S-IPWP to understand regional thermal-hydrological changes and interhemispheric teleconnections.

\section{Material and methods}

Site MD05-2925 $\left(9.3^{\circ} \mathrm{S}, 151.5^{\circ} \mathrm{E}\right.$, water depth $\left.1661 \mathrm{~m}\right)$ is located at the northern slope of the Woodlark Basin in the Solomon Sea, which is the passage of surface and subsurface water masses between low- and middle-latitude South Pacific Ocean gyre and cross equatorial currents (Grenier et al., 2011; Melet et al., 2011) (Fig. 1). The seasonal precipitation in this region (Fig. 1) is dominated by the AAM system, coupled with the intertropical convergence zone (ITCZ) (Shiau et al., 2012, and references therein). Tests of single species planktonic foraminifera, Globigerinoides sacculifer (> $500 \mu \mathrm{m}$, total amount of $2-6 \mathrm{mg}$ ), at 13 selected depths were picked for accelerator mass spectrometry (AMS) ${ }^{14} \mathrm{C}$ dating. The AMS dates were calibrated using the CALIB 6.0.1 program (Table 1; Reimer et al., 2009; Stuiver et al.,
Table 1. AMS ${ }^{14} \mathrm{C}$ dates of site MD05-2925.

\begin{tabular}{lrrrr}
\hline $\begin{array}{l}\text { Depth } \\
(\mathrm{cm})\end{array}$ & $\begin{array}{r}{ }^{14} \text { C ages } \\
\text { (years) }\end{array}$ & $\begin{array}{r}\text { Error } \\
\text { (years) }\end{array}$ & $\begin{array}{r}\text { Cal. ages } \\
\text { (years) }\end{array}$ & $\begin{array}{r}\text { Error } \\
\text { (years) }\end{array}$ \\
\hline 117 & 8823 & 50 & 9414 & 111 \\
$127^{*}$ & 10306 & 70 & 11259 & 159 \\
140 & 10441 & 30 & 11333 & 80 \\
$147^{*}$ & 11477 & 70 & 12854 & 110 \\
157 & 12066 & 60 & 13391 & 84 \\
$172^{*}$ & 13117 & 70 & 14973 & 309 \\
180 & 13748 & 35 & 16283 & 453 \\
$192^{*}$ & 14080 & 74 & 16746 & 223 \\
$207^{*}$ & 15616 & 75 & 18201 & 175 \\
217 & 16470 & 81 & 19083 & 90 \\
$262^{*}$ & 18985 & 94 & 22167 & 181 \\
$272^{*}$ & 20960 & 150 & 24411 & 167 \\
$292^{*}$ & 21650 & 78 & 25304 & 339 \\
\hline
\end{tabular}

* Samples were measured in the NSF-Arizona AMS Laboratory of the University of Arizona (U. Arizona), Tucson, USA, and the others were measured in the Rafter Radiocarbon Laboratory, Institute of Geological and Nuclear Science (GNS), New Zealand.

2010) to reconstruct an age model for a time interval from 23 to $10.5 \mathrm{ka}$.

In total, 40-60 individuals of the planktonic foraminifera Globigerinoides ruber (white, s.s., 250-300 $\mu \mathrm{m}$ ) were picked under the microscope. For Mg/Ca measurements, 20-30 individuals were gently crushed and transported into a $1.5 \mathrm{~mL}$ Teflon vial. The foraminiferal fragments were cleaned sequentially in the following solutions: (1) ethanol, (2) $\mathrm{H}_{2} \mathrm{O}_{2}$ $(0.45 \mathrm{~mL}, 3 \%)$, (3) $\mathrm{NH}_{4} \mathrm{Cl}(0.45 \mathrm{~mL}, 1.0 \mathrm{~N})$, (4) $\mathrm{NH}_{2} \mathrm{OH}$ $(0.45 \mathrm{~mL}, 0.01 \mathrm{~N})$, and (5) dilute nitric acid $(1 \mathrm{~mL}, 0.005 \mathrm{~N}$; Shen et al., 2001). A sector field inductive coupled plasma mass spectrometer (SF-ICP-MS), Thermo Electron Element II, housed at the High-Precision Spectrometry and Environment Change Laboratory (HISPEC), Department of Geosciences, National Taiwan University, was used to determine trace element/Ca ratios following the methodology developed by Shen et al. (2007). The detailed cleaning procedure and methodology are described by Lo et al. (2014). The 2year $1 \sigma$ reproducibility of $\mathrm{Mg} / \mathrm{Ca}$ analyses is $\pm 0.21 \%$ (Lo et al., 2014). We used the composite $\mathrm{Mg} / \mathrm{Ca}-\mathrm{SST}$ equation of Anand et al. (2003) to calculate SSTs.

For oxygen stable isotope analysis, 7-10 individuals were immersed in methanol, ultrasonicated for $10 \mathrm{~s}$, and then rinsed with deionized water 5 times. Samples were immersed afterward in sodium hyperchlorite $(\mathrm{NaOCl})$ for $24 \mathrm{~h}$, and then analyzed with an isotopic ratio mass spectrometer (IRMS), Micromass IsoPrime, at the National Taiwan Normal University. The long-term $1 \sigma$ precision of this instrument is better than $\pm 0.05 \%$ o $(\mathrm{N}=701$, Lo et al., 2013) and data are reported with respect to the Vienna Pee Dee Belemnite (VPDB) standard through the calibration of NBS-19 (National Bureau Standards; $\delta^{13} \mathrm{C}=1.95 \%$ o, $\delta^{18} \mathrm{O}=-2.20 \%$ ). 


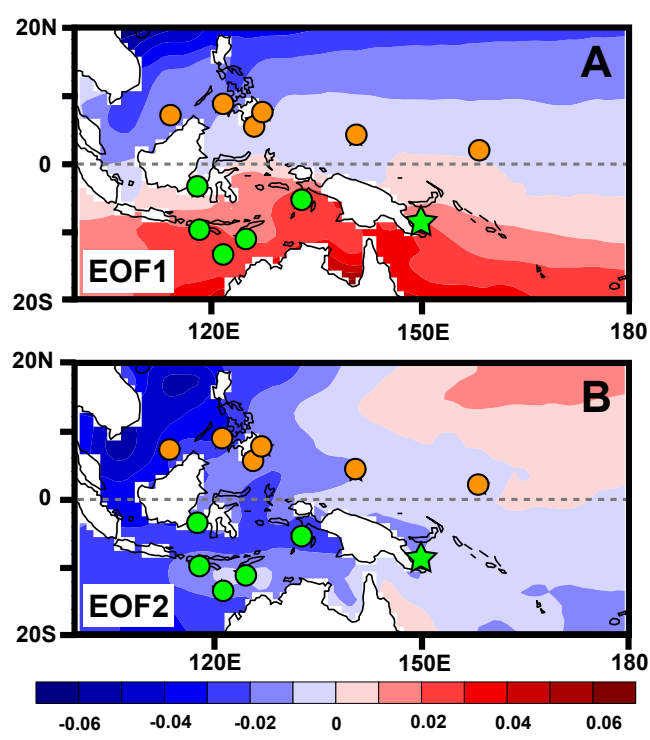

Figure 2. EOF analysis on SST (data set from Reynolds et al., 2002) and selected sites (Table 2) used for stacked N- and S-IPWP records. (a) EOF1 explains $83.4 \%$ of the total variance, which mainly represents intra-annual seasonality. (b) EOF2 shows a clear zonal pattern. Orange circles represent selected sites for the N-IPWP group and green ones for the S-IPWP group. The green star denotes the MD05-2925 site used in this study.

To extract seawater $\delta^{18} \mathrm{O}\left(\delta^{18} \mathrm{O}_{\mathrm{SW}}\right)$ values, we used a cultural-based equation, $\mathrm{SST}=16.5-4.8 \times\left(\delta^{18} \mathrm{O}_{\mathrm{C}}-\right.$ $\delta^{18} \mathrm{O}_{\text {SW }}$ ) (Bemis et al., 1998) and a constant offset of $0.27 \%$ between carbonate VPDB and Vienna Standard Ocean Water (VSMOW) scales. Ice volume-corrected $\delta^{18} \mathrm{O}_{\mathrm{SW}}$ $\left(\delta^{18} \mathrm{O}_{\mathrm{SW}-\mathrm{IVC}}\right)$ was calculated using the method proposed by Waelbroeck et al. (2002).

The empirical orthogonal function (EOF) analysis of a modern SST data set (AD 1950-2004; Reynolds et al., 2002) for a sector from $20^{\circ} \mathrm{S}$ to $20^{\circ} \mathrm{N}$, and 100 to $180^{\circ} \mathrm{E}$ was conducted (Fig. 2) to determine the boundary between $\mathrm{N}$ IPWP and S-IPWP. With an equatorial border, the EOF1 factor $(83.4 \%)$ effectively resolved SST variation groups. The EOF2 factor shows minor (9.7\%) but significant interannual zonal (ENSO) control on the SST patterns. EOF results show that the geographic equator is also the thermal equator between N-IPWP and S-IPWP (Fig. 2).

To build a stacked N- and S-IPWP record, we followed the suggestions of Leduc et al. (2010) and considered three criteria for this data set: (1) sites with locations from $12^{\circ} \mathrm{N}$ to $15^{\circ} \mathrm{S}$, which is the main IPWP range (Yan et al., 1992; Gagan et al., 2004), and (2) usage of specific proxies, $\mathrm{Mg} / \mathrm{Ca}$-derived SST and $\delta^{18} \mathrm{O}_{\mathrm{C}}$ records of planktonic foraminifera, G. ruber (white, s.s.). Records from 12 sites were selected, including this study (Table 2). We adopted the published age model for sites ODP806, MD97-2140, MD97-2141, MD98-2162, MD98-2170, MD98-2176, and MD98-2181. For records with available original radiocarbon
Table 2. Selected sites for stacked N- and S-IPWP records.

\begin{tabular}{lll}
\hline Core & $\begin{array}{l}\text { Location } \\
\text { (latitude, longitude) }\end{array}$ & References \\
\hline \multicolumn{3}{c}{ North-IPWP group (orange circles in Figs. 1 and 2) } \\
\hline ODP806 & $0.3^{\circ} \mathrm{N}, 159.4^{\circ} \mathrm{E}$ & Lea et al. (2000) \\
MD97-2140 & $2.0^{\circ} \mathrm{N}, 141.7^{\circ} \mathrm{E}$ & de Garidel-Thoron et al. (2005) \\
MD98-2181 & $6.3^{\circ} \mathrm{N}, 125.8^{\circ} \mathrm{E}$ & Stott et al. (2002, 2004) \\
MD06-3067 & $6.5^{\circ} \mathrm{N}, 126.5^{\circ} \mathrm{E}$ & Bolliet et al. (2011) \\
MD97-2141 & $8.8^{\circ} \mathrm{N}, 121.3^{\circ} \mathrm{E}$ & Rosenthal et al. (2003) \\
MD01-2390 & $12.1^{\circ} \mathrm{N}, 113.2^{\circ} \mathrm{E}$ & Steinke et al. (2006) \\
\hline \multicolumn{2}{c}{ South-IPWP group (green circles and star in Figs. 1 and 2) } \\
\hline MD98-2162 & $4.4^{\circ} \mathrm{S}, 117.5^{\circ} \mathrm{E}$ & Visser et al. (2003) \\
MD98-2176 & $5.0^{\circ} \mathrm{S}, 133.4^{\circ} \mathrm{E}$ & Stott et al. (2004) \\
MD05-2925 & $9.3^{\circ} \mathrm{S}, 151.5^{\circ} \mathrm{E}$ & This study \\
MD98-2165 & $9.7^{\circ} \mathrm{S}, 118.3^{\circ} \mathrm{E}$ & Levi et al. (2007) \\
MD98-2170 & $10.6^{\circ} \mathrm{S}, 125.4^{\circ} \mathrm{E}$ & Stott et al. (2004) \\
MD01-2378 & $13.1^{\circ} \mathrm{S}, 121.7^{\circ} \mathrm{E}$ & Xu et al. (2008) \\
\hline
\end{tabular}

ages from sites, including MD01-2378, MD01-2390, MD982165, and MD06-3067, we recalculated the age models using the CALIB 6.0.1 program. The sea level change effect on $\delta^{18} \mathrm{O}_{\mathrm{SW}}$ was also corrected. We divided the total data into 400 -year windows and calculated the mean and standard error of the mean for each time window.

\section{Results and discussion}

\subsection{Geochemical proxy data at site MD05-2925}

Planktonic foraminiferal geochemical proxy data for site MD05-2925 are shown in Fig. 3. G. ruber $\delta^{18} \mathrm{O}_{\mathrm{C}}$ varies from -1.0 to $-2.3 \%$ and shows no significant millennial timescale variations. $\mathrm{Mg} / \mathrm{Ca}$ ratios feature stable glacial values of $\sim 3.5 \mathrm{mmol} \mathrm{mol}^{-1}$ and rapid increasing transitions of $0.5-1.0 \mathrm{mmol} \mathrm{mol}^{-1}$ at $\sim 18.5,16.5,14.5$, and $12.8 \mathrm{ka}$. The glacial-interglacial variation of calculated seawater $\delta^{18} \mathrm{O}_{\mathrm{SW}}$ changes is $\sim 1 \%$. Two abrupt decreases of $0.6-0.8 \%$ are observed at 14.6 and $11.8 \mathrm{ka}$.

\subsection{Solomon SST and $\delta^{18} \mathrm{O}_{\mathrm{SW}-\mathrm{IVC}}$ records during the last termination}

$\mathrm{Mg} / \mathrm{Ca}$ SST records of the planktonic foraminifera $G . r u$ ber reveal stable glacial thermal conditions during the period $23.0-18.5 \mathrm{ka}$, with a variation $<1^{\circ} \mathrm{C}$ and a glacialinterglacial difference of $\sim 3{ }^{\circ} \mathrm{C}$ between the last glacial maximum (LGM) and the end of the Younger Dryas (YD) in the Solomon Sea (Fig. 4a). This record is characterized by (i) the end of glacial conditions at $18.5 \mathrm{ka}$, and (ii) rapid SST increases of $1-2{ }^{\circ} \mathrm{C}$ at $18.5-18.0,17.0-16.0,15.0-14.5$, and $13.0-12.5 \mathrm{ka}$.

The onset of deglacial SST increases in this region is consistent with the timing of thermal changes in the Southern Ocean as inferred from Antarctic ice core $\delta$ D records (Stenni et al., 2003) (Fig. 4a). This agreement indicates a strong cli- 


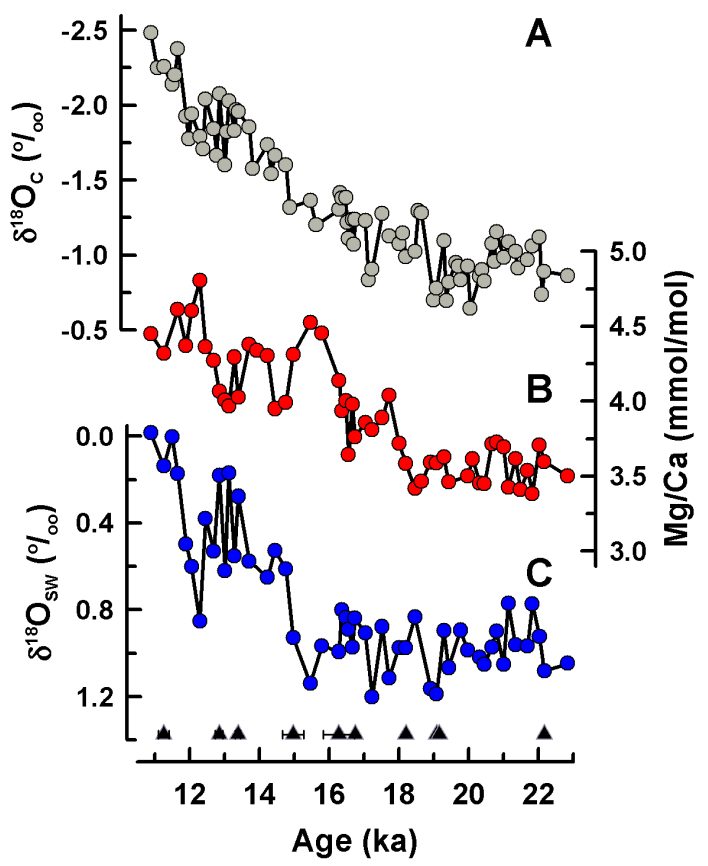

Figure 3. Planktonic foraminifera G. ruber geochemical proxy records of site MD05-2925, including (a) oxygen isotope $\left(\delta^{18} \mathrm{O}_{\mathrm{C}}\right)$, (b) $\mathrm{Mg} / \mathrm{Ca}$ ratio, and (c) temperature corrected-only seawater oxygen isotope $\left(\delta^{18} \mathrm{O}_{\mathrm{SW}}\right)$. Triangle symbols are corrected radiocarbon dates (Table 1).

matic teleconnection between low- and high-latitude realms in the Southern Hemisphere (SH), as well as change of greenhouse gas concentrations (Mohtadi et al., 2014). There are significant SST increases of $1-2{ }^{\circ} \mathrm{C}$ during Heinrich event 1 (H1) and the YD. Previous studies from the eastern equatorial and South Pacific reveal a mechanism characterized by early warming of South Pacific subtropical mode water (Pahnke et al., 2003; Lamy et al., 2004; Pena et al., 2008). This warm signal is transported along a gyre to the east equatorial Pacific (EEP) and eventually to the west Pacific through ocean tunneling (Pena et al., 2008; Qu et al., 2013, Fig. 4a). Our new SST record is similar to those in the EEP (Pena et al., 2008) and eastern Indian Ocean records (Xu et al., 2008; Mohtadi et al., 2014) for both termination timing (within dating error) and significant warming during the $\mathrm{H} 1$ and YD events. There is a slight warming $\left(<1{ }^{\circ} \mathrm{C}\right)$ interval at $14.5-13.5 \mathrm{ka}$ during the B/A (Bølling/Allerød) period (Fig. 4a). The warming could be attributed to possible mixing with warm surface waters of the N-IPWP.

The Solomon Sea $\delta^{18} \mathrm{O}_{\mathrm{SW}-\mathrm{IVC}}$ record is given in Fig. $4 \mathrm{~b}$. It varies from -0.5 to $0.1 \%$ during $23.0-10.5 \mathrm{ka}$. A relatively stable condition with $1 \sigma$ variability of $0.1 \%$ from 23.0 to $16.0 \mathrm{ka}$. Two significant positive excursions with $0.2-$ $0.5 \%$ enrichments in $\delta^{18} \mathrm{O}$ are observed in the intervals $16.8-15.0 \mathrm{ka}$, and $13.8-11.8 \mathrm{ka}$. Two stable periods with low $\delta^{18} \mathrm{O}_{\mathrm{SW}-\mathrm{IVC}}$ of $-0.4 \%$ occurred between $15.0-13.0 \mathrm{ka}$ and after $11.8 \mathrm{ka}$.

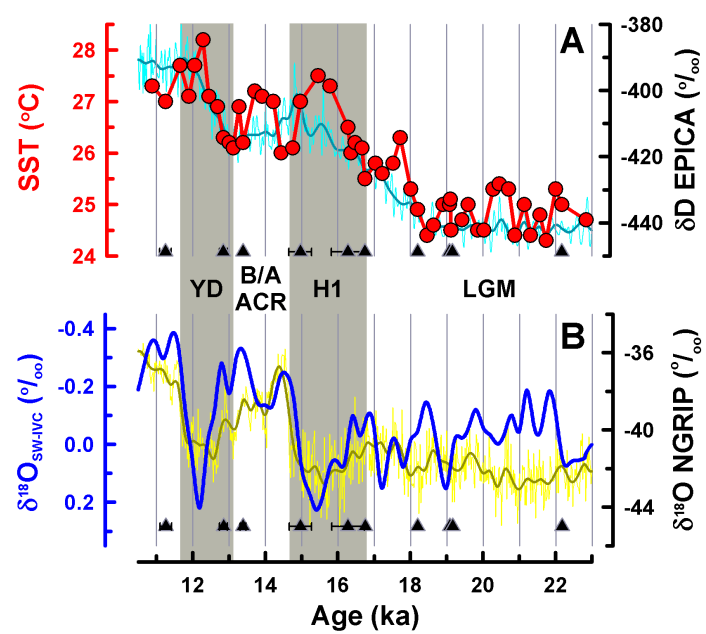

Figure 4. Geochemical proxy records of MD05-2925. (a) SST (red circles and line) and (b) $\delta^{18} \mathrm{O}_{\mathrm{SW}-\mathrm{IVC}}$ (blue line) were reconstructed with $G$. ruber $\mathrm{Mg} / \mathrm{Ca}$ ratios and $\delta^{18} \mathrm{O}_{\mathrm{C}}$. The cyan line denotes the Antarctica EPICA (European Project for Ice Coring in Antarctica) deuterium isotope record (Stenni et al., 2003), and the yellow line is the Greenland ice core NGRIP (Northern Greenland Ice Core Project Members, 2004) oxygen isotope record. The superimposed dark cyan and dark yellow lines are the 200 a smoothed records, respectively. Black triangles are AMS ${ }^{14} \mathrm{C}$ dates (Table 1). Vertical bars denote the $\mathrm{H} 1$ and YD periods.

The dramatic $\delta^{18} \mathrm{O}_{\mathrm{SW}-\mathrm{IVC}}$ increases during $\mathrm{H} 1$ and the YD likely resulted from a weakening and/or southward shift of the ITCZ (Chiang and Bitz, 2005; Broccoli et al., 2006), and local evaporation may also play a role. Agreement between the $\delta^{18} \mathrm{O}$ sequences of the Greenland NGRIP (Northern Greenland Ice Core Project) ice core and the Solomon Sea $\delta^{18} \mathrm{O}_{\mathrm{SW}-\mathrm{IVC}}$ indicates an imprint from the high-latitude Northern Hemisphere $(\mathrm{NH})$ during the last termination period (Shakun and Carlson, 2010) (Fig. 4b).

\subsection{Millennial timescale variations of N- and S-IPWP SST stacks}

Both N- and S-IPWP stacked SSTs show the same difference of $\sim 3{ }^{\circ} \mathrm{C}$ between the last glacial and interglacial states (Fig. 5a). N-IPWP stacked SST values increased steadily since $18 \mathrm{ka}$ through the termination at a rate of $0.5^{\circ} \mathrm{C} \mathrm{ka}^{-1}$. Millennial timescale variability is absent in this record, which is similar to Linsley et al. (2010) and Stott et al. (2002). Although the resolutions of ODP806 and MD972140 are insufficient to resolve the millennial-timescale event, there is no significant difference with/without their records in our N-IPWP stacks (not shown).

The onset of the termination at $\sim 19 \mathrm{ka}$ in the S-IPWP stack is consistent with temperature increases in Antarctica (Stenni et al., 2003), and occur about $1 \mathrm{kyr}$ earlier than in the N-IPWP stack (Fig. 5a). This timing is synchronous with EEP (Pena et al., 2008) and SST records of the nonupwelling 


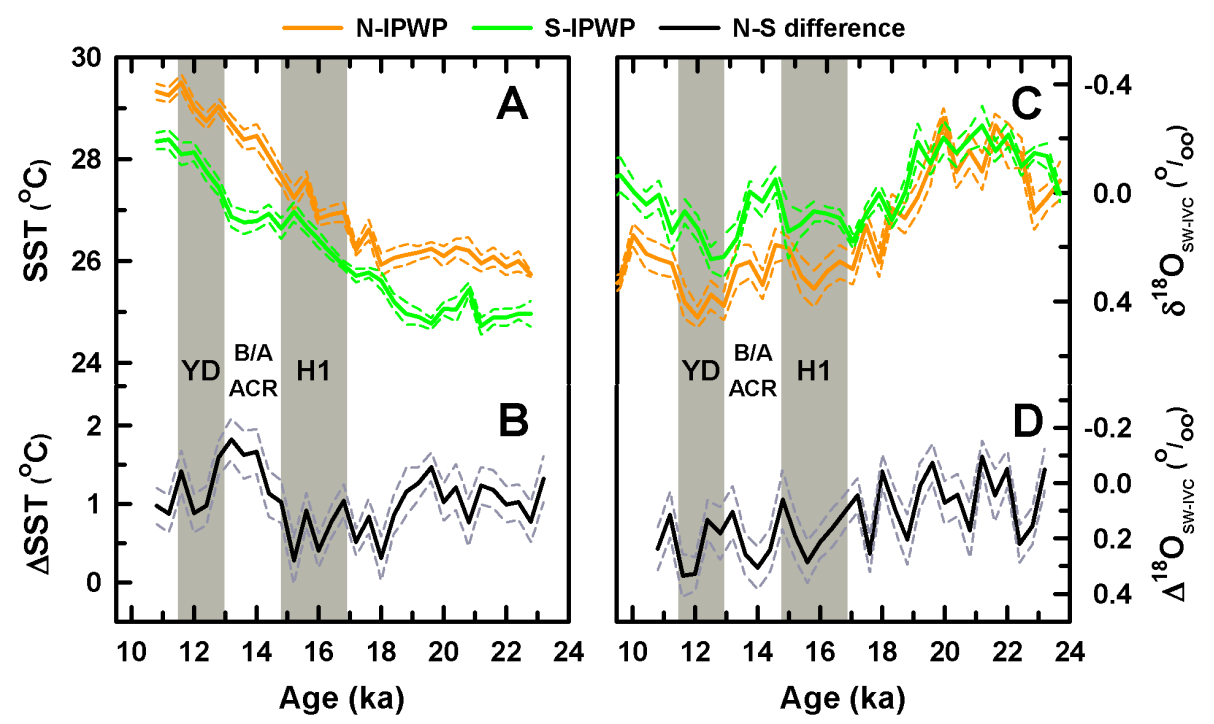

Figure 5. Four-hundred-year nonoverlapping binned (a) SST and (c) $\delta^{18} \mathrm{O}_{\mathrm{SW}-\mathrm{IVC}}$ of N- (orange solid line) and S-IPWP (green solid line). Lower panels show the differences in (b) SST and (d) $\delta^{18} \mathrm{O}_{\mathrm{SW}-\mathrm{IVC}}$ between N- and S-IPWP. The compilations of N- and S-IPWP surface water thermal and hydrological records (Table 2) were calculated with the nonoverlapping binned methods (Oppo et al., 2009; Linsley et al., 2010). All dashed lines represent $1 \sigma$ uncertainty ranges. Gray bars show the H1 and YD events.

region of the eastern Indian Ocean (Xu et al., 2008; Mohtadi et al., 2014). Thus, our MD05-2925 and S-IPWP stacked SST does not appear to be severely affected by equatorial upwelling. Instead, the S-IPWP stacked SST record represents the broad SH equatorial region thermal conditions applicable to upwelling and nonupwelling E-W equatorial environments of both the Indian and Pacific oceans. Records from the tropical South China Sea show interproxy $\left(\mathrm{U}_{37}^{K^{\prime}}\right.$ and $\mathrm{Mg} / \mathrm{Ca}$ ) differences during $\mathrm{H} 1$ and the $\mathrm{YD}$ (Zhao et al., 2006; Steinke et al., 2008), probably due to intrinsic limitations of the different proxies, such as seasonality and upwelling intensity. The S-IPWP stacked SST record is characterized by a warming trend during $\mathrm{H} 1$ and the $\mathrm{YD}$, similar to Antarctic ice core temperature records (Stenni et al., 2003), and a steady thermal condition at $\sim 27^{\circ} \mathrm{C}$ during the B/A, corresponding to the Antarctic cold reversal (ACR) (Fig. 5a).

The thermal gradient between the $\mathrm{N}$ - and S-IPWP is around $1{ }^{\circ} \mathrm{C}$ from 23 to $19 \mathrm{ka}$. Due to the earlier S-IPWP warming, the thermal gradient dropped from 1 to $0.5^{\circ} \mathrm{C}$ around $19-18 \mathrm{ka}$, and persisted to the end of the $\mathrm{H} 1$ event. The largest observed thermal gradient $\left(1.5-2.0^{\circ} \mathrm{C}\right)$ occurred during the $\mathrm{B} / \mathrm{A}$ period, and was followed by a $1^{\circ} \mathrm{C}$ drop during the YD. The meridional SST gradient between $\mathrm{N}-$ and S-IPWP over the last termination is attributed to the large thermal variability in the S-IPWP (Fig. 5a). Asynchroneity between persistent N-IPWP and fluctuating S-IPWP SST sequences (Fig. 5a) indicates a meridionally dynamic IPWP through the last termination period. This N-S SST gradient variability would also affect interhemispheric air flow and heat transport (Gibbons et al., 2014; McGee et al., 2014), providing a mechanism to explain heat transport variability between the hemispheres on a millennial timescale.

\section{4 $\mathrm{N}$ - and S-IPWP $\delta^{18} \mathrm{O}_{\mathrm{SW}-\mathrm{IVC}}$ records}

Both the N- and S-IPWP $\delta^{18} \mathrm{O}_{\mathrm{SW}-\mathrm{IVC}}$ records feature (1) low values of $-0.3-0.0 \%$ during glacial times, and (2) increasing trends after $19 \mathrm{ka}$ (Fig. $5 \mathrm{c}$ ). The gradient between $\mathrm{N}$ - and S-IPWP gradually increased from 0 to $0.2 \%$ o through the termination (Fig. 5d). A similar pattern of $\delta^{18} \mathrm{O}_{\mathrm{SW}-\mathrm{IVC}}$ between the N- and S-IPWP suggests that hydrological conditions in the two regions were governed by the same factor(s), probably related to Northern Atlantic cold perturbations (Shakun and Carlson, 2010). It has also been suggested that a major $\delta^{18} \mathrm{O}_{\mathrm{SW}-\mathrm{IVC}}$ increase during the $\mathrm{H} 1$ and YD periods in the IPWP region likely resulted from reduced precipitation and oceanic advection in both the N-IPWP and S-IPWP regions (Gibbons et al., 2014; McGee et al., 2014).

\subsection{Meridional IPWP SST gradient and a southward-shift of the ITCZ precipitation boundary}

A striking feature of the stacked SST records is the warming in the S-IPWP during the H1 and YD periods (Fig. 5a). Observations over the past 6 decades (Fig. 12 in Feng et al., 2013) show that an equatorward shift of the NH convection branch of the Hadley cell (HC) could result from an oceanic warming at $\sim 10^{\circ} \mathrm{S}$. This equatorward shift could induce a southward ITCZ shift of about $10^{\circ}$ (Feng et al., 2013). Model simulations (Chiang and Bitz, 2005; Broccoli et al., 2006; Lee et al., 2011) suggest that this altered circulation provides 


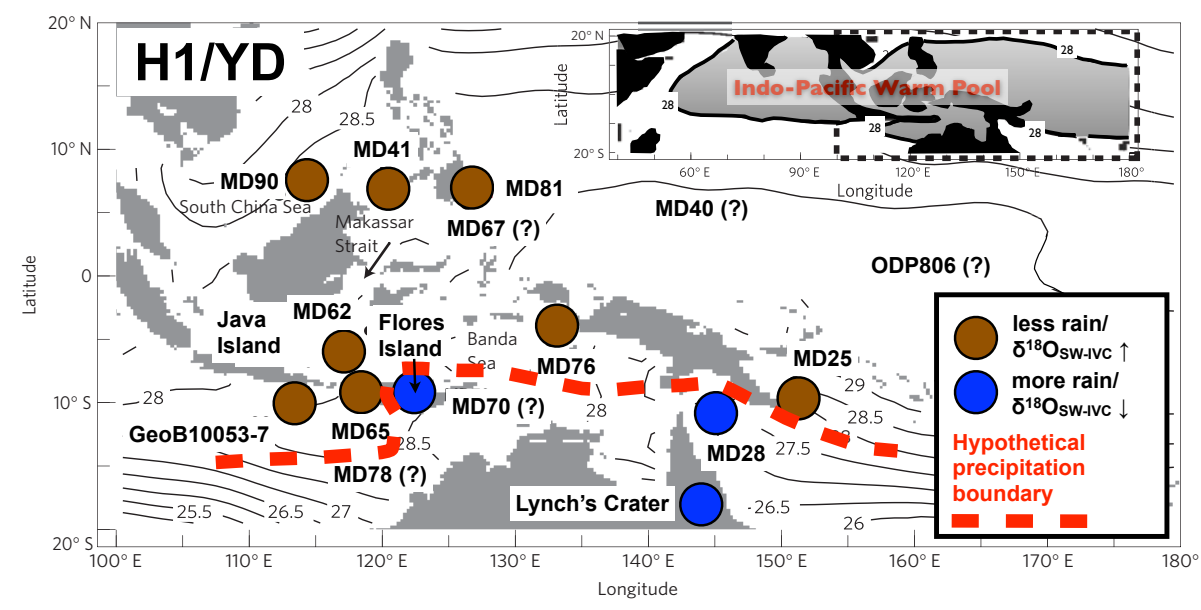

Figure 6. Hypothetical proxy-inferred precipitation boundary during the $\mathrm{H} 1$ and YD events (modified from the Linsley et al., 2010). Blue dots represent a relatively increasing precipitation $/ \delta^{18} \mathrm{O}_{\mathrm{SW}}$ lighter condition, and brown dots a decreasing precipitation $/ \delta^{18} \mathrm{O}_{\mathrm{SW}}$ heavier condition. The segment between the Java and Flores islands of this sharp boundary (red dashed line) was proposed by Mohtadi et al. (2011), and the one between the Solomon and Coral seas by this study. Black contours represent SST.

a powerful teleconnection between the $\mathrm{NH}$ and $\mathrm{SH}$ climate systems through a coupled tropical ocean-atmosphere pathway, and is supported by marine and terrestrial hydrological proxy data (Y. J. Wang et al., 2001; Lea et al., 2003; X. Wang et al., 2007; Griffiths et al., 2009; Shakun and Carlson, 2010; Mohtadi et al., 2011; Meckler et al., 2012; Ayliffe et al., 2013; Carolin et al., 2013; Gibbons et al., 2014; McGee et al., 2014, Fig. 6).

Distinctly different precipitation conditions across 8$10^{\circ} \mathrm{S}$ in the IPWP during the H1 and YD events are illustrated in Fig. 6. For example, enhanced terrestrial sediment flux into the Coral Sea is suggested by a marine sediment thorium isotopic proxy record at $11^{\circ} \mathrm{S}$ (Shiau et al. 2011). Lynch's crater records from northeastern Australia at $17^{\circ} \mathrm{S}$ (Muller et al., 2008) show strong Australian summer monsoonal conditions. Stalagmite $\delta^{18} \mathrm{O}$ records at Flores Island $\left(8^{\circ} \mathrm{S}\right)$ also feature intense precipitation during $\mathrm{H} 1$ and the YD (Griffiths et al., 2009; Ayliffe et al., 2013). However, marine and stalagmite $\delta^{18} \mathrm{O}$ evidence reveal conditions of reduced precipitation and increased salinity in the northern IPWP, north of $8-10^{\circ} \mathrm{S}$, including the South China Sea $\left(12^{\circ} \mathrm{N}\right.$; Steinke et al., 2006), Sulu Sea $\left(8^{\circ} \mathrm{N}\right.$; Rosenthal et al., 2003), Philippine Sea ( $6^{\circ} \mathrm{N}$; Stott et al., 2002; Boillet et al., 2011), Java Island ( $8^{\circ} \mathrm{S}$; Mohtadi et al., 2011), Solomon Sea $\left(9^{\circ} \mathrm{S}\right.$; this study), and Borneo island $\left(4^{\circ} \mathrm{N}\right.$; Meckler et al., 2012; Carolin et al., 2013) (Fig. 6). On the basis of previous terrestrial and marine hydrological records and our new data, as well as modern (Feng et al., 2013) and simulated (Chiang and Bitz, 2005; Broccoli et al., 2006) data, we speculate a sharp precipitation boundary between the maritime continents and Australia at about $8-10^{\circ} \mathrm{S}$, extending from the Solomon Sea, Arafura Sea and Timor Sea, to the eastern Indian Ocean during H1 and the YD (Fig. 6). We propose that the west and east boundaries are between the Java-
Flores islands (Griffiths et al., 2009; Mohtadi et al., 2011), and Solomon-Coral seas, respectively (Shiau et al., 2011; this study). A geographical mismatch between $\mathrm{N}$ - and SIPWP thermal and precipitation patterns could be associated with the complex island mountain range configurations and sea level changes (Linsley et al., 2010).

To sum up our geochemical and composite data set in the IPWP region during the last terminations, we propose that the enlarged IPWP meridional SST gradient could result in an altered $\mathrm{HC}$ and reduced (increased) precipitation for the east Asian (Australia) monsoon territories during the $\mathrm{H} 1$ and YD periods (McGee et al., 2014). We also propose that variations in the meridional IPWP SST gradient during the termination period were mainly caused by the S-IPWP, which is closely linked to high-latitude climate systems.

\section{Conclusions}

Our new MD05-2925 marine geochemical records and stacked SSTs suggest that the meridional IPWP thermal conditions are strongly linked to interhemispheric high-latitude climate during the last deglaciation. Ice-volume-corrected $\delta^{18} \mathrm{O}_{\mathrm{SW}}$ stacked records show an increasing salinity gradient between N- and S-IPWP over the last termination. However, the $\delta^{18} \mathrm{O}_{\mathrm{SW}-\mathrm{IVC}}$ could be affected by complex mountain range configurations in the IPWP region, and sea-levelcontrolled openings/connections among semiclosed seas. Here we propose a new process of the thermal evolution of the IPWP region, where meridional differences in the thermal gradient could amplify the signal from high-latitude Northern Hemisphere climate events (e.g., H1, B/A and the YD), and radiative forcing from greenhouse gases. A hypothetical precipitation boundary around $8-10^{\circ} \mathrm{S}$ during $\mathrm{H} 1$ and the 
YD has also been proposed, which is most likely caused by the meridional IPWP SST gradient and HC anomalies. We suggest that more advanced high-resolution regional model simulations are required to clarify (1) local precipitation variations in response to the complicated sea level and convection changes, (2) the role of the IPWP meridional thermalhydrological gradient to an altered $\mathrm{HC}$, and (3) its relationship with regional and global climate systems during global climate perturbation events.

Acknowledgements. The MD05-2925 site location was selected by Min-Te Chen and Meng-Yang Lee and collected during the IMAGES PECTEN cruise, conducted by Luc Beaufort and Min-Te Chen. Chien-Ju Chou, Wan-Lin Hu, and Yu-Ting Hsiao helped to pick foraminifera samples. Yang-Hui Hsu helped to operate the climatological database and plotted figures. Thanks to Delia W. Oppo and Braddock K. Linsley for their generous offering of the nonoverlapping method MatLab code. This research was funded by the Taiwan ROC MOST (99-2611-M-002-005, 100-2116-M-002-009 and 103-2119-M-002-022 to C.-C. Shen; 95-2611-M-002-019 and 96-2611-M-002-019 to K.-Y. Wei), and the National Taiwan University (101R7625 to C.-C. Shen).

Edited by: E. McClymont

\section{References}

Anand, P. A., Elderfield, H., and Conte, M. H.: Calibration of $\mathrm{Mg} / \mathrm{Ca}$ thermometry in planktonic foraminifera from a sediment trap time series, Paleoceanography, 18, 1050, doi:10.1029/2002PA000846, 2003.

Ayliffe, L. K., Gagan, M. K., Zhao, J.-X., Drysdale, R. N., Hellstrom, J. C., Hantoro, W. S., Griffiths, M. L., ScottGagan, H., Pierre, E. S, Cowley, J. A., and Suwargadi, B. W.: Rapid interhemispheric climate links via the Australasian monsoon during the last deglacialtion, Nature Commun., 4, 2908, doi:10.1038/ncomms3908, 2013.

Bemis, B. E., Spero, H. J., Bijma, J., and Lea, D. W.: Reevaluation of the oxygen isotopic composition of planktonic foraminifera: Experimental results and revised paleotemperature equations, Paleocenography, 13, 150-160, 1998.

Bolliet, T., Holbourn, A., Kuhnt, W., Laj, C., Kissel, c., Beaufort, L., Kienast, M., Andersen, N., and Garbe-Schönberg, D.: Mindanao Dome variability over the last $160 \mathrm{kyr}$ : Episodic glacial cooling of the West Pacific Warm Pool, Paleoceanography, 26, PA1208, doi:10.1029/2010PA001966, 2011.

Broccoli, A. J., Dahl, K. A., and Stouffer, R. J.: Response of the ITCZ to Northern Hemisphere cooling, Geophys. Res. Lett., 33, L01702, doi:10.1029/2005GL024546, 2006.

Carolin, S. A., Cobb, K. M., Adkins, J. F., Clark, B., Conroy, J. L., Lejau, S., Malang, J., and Tuen, A. A.: Varied response of Western Pacific hydrology to climate forcings over the last glacial period, Science, 340, 1564-1566, 2013.

Chiang, J. C. H. and Bitz, C. M.: Influence of high latitude ice cover on the marine Intertropical Convergence Zone, Clim. Dynam., 25, 477-496, 2005.
Cravatte, S., Delcroix, T., Zhang, D., McPhaden, M., and Leloup, J.: Observed freshening and warming of the western Pacific Warm Pool, Clim. Dynam., 33, 565-589, 2009.

de Garidel-Thoron, T., Rosenthal, Y., Bassinot, F., and Beaufort, L.: Stable sea surface temperatures in the western Pacific warm pool over the past 1.75 million years, Nature, 433, 294-298, 2005.

Feng, J., Li, J., and Xie, F.: Long-term variation of the Principal mode of boreal spring Hadley Circulation linked to SST over the Indo-Pacific Warm Pool, J. Clim., 26, 532-544, 2013.

Gagan, M., Hendy, E. J., Haberle, S. G., and Hantoro, W. S.: Postglacial evolution of the Indo-Pacific Warm Pool and El NiñoSouthern oscillation, Quaternary Int., 118-119, 127-143, 2004.

Gibbons, F. T., Oppo, D. W., Mohtadi, M., Rosenthal, Y., Cheng, J., Liu, Z., and Linsley, B. K.: Deglacial ${ }^{18} \mathrm{O}$ and hydrological variability in the tropical and Indian Oceans, Earth Planet. Sci. Lett., 387, 240-251, 2014.

Grenier, M., Cravatte, S., Blanke, B., Menkes, C., Joch-Larrouy, A., Durand, F., Melet, A., and Jeandel, C.: From the western boundary currents to the Pacific Equatorial Undercurrent: Modeled pathways and water mass evolutions, J. Geophys. Res., 116, C12044, doi:10.1029/2011JC007477, 2011.

Griffiths, M. L., Drysdale, R. N., Gagan, M. K., Zhao, J.-X., Ayliffe, L. K., Hellstrom, J. C., Hantoro, W. S., Frisia, S., Feng, Y.-X., Cartwright, I., St. Pierre, E., Fischer, M., J., and Suwargadi, B. W.: Increasing Australian-Indonesian monsoon rainfall linked to early Holocene sea-level rise, Nature Geosci., 2, 636-639, 2009.

Lamy, F., Kaiser, J., Ninnemann, U., Hebbeln, D., Arz, H. W., and Stoner, J.: Antarctic timing of surface water changes off Chile and Patagonian ice sheet response, Science, 304, 1959-1962, 2004.

Lea, D. W., Pak, D. K., and Spero, H. J.: Climate impact of late Quaternary equatorial Pacific sea surface temperature variations, Science, 289, 1719-1724, 2000.

Lea, D. W., Pak, D. K., Peterson, L. C., and Hughen, K. A.: Synchroneity of tropical high-latitude Atlantic temperatures over the last glacial termination, Science, 301, 1361-1364, 2003.

Leduc, G., Schneider, R., Kim, J. H., and Lohmann, G.: Holocene and Eemian sea surface temperature trends as revealed by alkenone and $\mathrm{Mg} / \mathrm{Ca}$ paleothermometry, Quaternary Sci. Rev., 29, 989-1004, 2010.

Lee, S.-Y., Chiang, J. C. H., Matsumoto, K., and Tokos, K.: Southern Ocean wind response to North Atlantic cooling and the rise in atmospheric $\mathrm{CO}_{2}$ : Modeling perspective and paleoceanographic implications, Paleoceanography, 26, PA1214, doi:10.1029/2010PA002004, 2011.

Levi, C., Labeyrie, L., Bassinot, F., Guichard, F., Cortijo, E., Waelbroeck, C., Caillon, N., Duprat, J., de Garidel-Thoron, T., and Elderfield, H.: Low-latitude hydrological cycle and rapid climate changes during the last deglaciation, Geochem. Geophy. Geosy., 8, Q05N12, doi:10.1029/2006GC001514, 2007.

Linsley, B. K., Rosenthal, Y., and Oppo, D. W.: Holocene evolution of the Indonesian throughflow and the western Pacific warm Pool, Nature Geosci., 3, 578-583, 2010.

Lo, L., Lai, Y.-H., Wei, K.-Y., Lin, Y.-S., Mii, H.-S., and Shen, C.C.: Persistent sea surface temperature and declined sea surface salinity in the northwestern tropical Pacific over the past 7500 years, J. Asian Earth Sci., 66, 234-239, 2013.

Lo, L., Shen, C.-C., Lu, C.-J., Chen, Y.-C., Chang, C.-C., Wei, K.Y., Qu, D., and Gagan, M. K.: Determination of element/Ca ra- 
tios in foraminifera and corals using cold- and hot-plasma techniques in inductively coupled plasma sector field mass spectrometry, J. Asian Earth Sci., 81, 115-122, 2014.

McGee, D., Donohoe, A., Marshall, J., and Ferreira, D.: Changes in ITCZ location and cross-equatorial heat transport at the Last Glacial Maximum, Heinrich Stadial 1, and the mid-Holocene, Earth Planet. Sci. Lett., 390, 69-79, 2014.

Meckler, A. N., Clarkson, M. O., Cobb, K. M., Sodemann, H., and Adkins, J. F.: Interglacial hydroclimate in the tropical West Pacific through the late Pleistocene, Science, 336, 1301-1304, 2012.

Melet, A., Verron, J., Gourdeau, L., and Koch-Larrouy, A.: Equatorial pathways of Solomon Sea water masses and their modification, J. Phys. Oceano., 40, 810-826, 2011.

Mohtadi, M., Oppo, D. W., Steinke, S., Stuut, J.-B. W., De Pol-Holz, R., Hebbeln, D., and Lückge, A.: Glacial to Holocene swings of the Australian-Indonesian monsoon, Nature Geosci., 4, 540-544, 2011.

Mohtadi, M. Prange, M., Oppo, D. W., De Pol-Holz, R., Merkel, U., Zhang, X., Stenike, S., and Lückge, A.: North Atlantic forcing of tropical Indian Ocean climate, Nature, 509, 76-80, 2014.

Muller, J., Kylander, M., Wüst, R. A. J., Weiss, D., MartinezCortizas, A., LeGrande, A. N., Jennerjahn, T., Behling, H., Andreson, W. T., and Jacobson, G.: Possible evidence for wet Heinrich phases in tropical Australia: the Lynch's Crater deposit, Quaternary Sci. Rev., 27, 468-475, 2008.

Northern Greenland Ice Core Project Members: High-resolution record of Northern Hemisphere climate extending into the last interglacial period, Nature, 431, 147-151, 2004.

Oppo, D. W., Rosenthal, Y., and Linsley, B. K.: 2,000-year-long temperature and hydrology reconstructions from the Indo-Pacific warm pool, Nature, 460, 1113-1116, 2009.

Pahnke, K., Zahn, R., Elderfield, H., and Schulz, M.: 340,000-year centennial-scale marine record of Southern Hemisphere climatic oscillation, Science, 301, 948-952, 2003.

Pena, L. D., Cacho, I., Ferretti, P., and Hall, M. A.: El NiñoSouthern Oscillation-like variability during glacial terminations and interlatitudinal teleconnections, Paleoceanography, 23, PA3101, doi:10.1029/2008PA001620, 2008.

Qu, T., Gao, S., and Fine, R. A.: Subduction of South Pacific tropical water and its equatorward pathways as shown by a simulated passive tracer, J. Phys. Oceanogr., 43, 1551-1565, 2013.

Reimer, P. J., Baillie, M. G. L., Bard, E., Bayliss, A., Beck, J. W., Blackwell, P. G., Bronk Ramsey, C., Buck, C. E., Burr, G. S., Edwards, R. L., Friedrich, M., Grootes, P. M., Guilderson, T. P., Hajdas, I., Heaton, T. J., Hogg, A. G., Hughen, K. A., Kaiser, K. F., Kromer, B., McCormac, F. G., Manning, S. W., Reimer, R. W., Richards, D. A., Southon, J. R., Talamo, S., Turney, C. S. M., van der Plicht, J., and Weyhenmeyer, C. E.: INTCAL09 and MARINE09 radiocarbon age calibration curves, 0-50,000 cal BP, Radiocarbon, 51, 1111-1150, 2009.

Reynolds, R. W., Rayner, N. A., Smith, T. M., and Stokes, D. C.: An improved in situ and satellite SST analysis for climate, J. Clim., 15, 1609-1625, 2002.

Rosenthal, Y., Oppo, D. W., and Linsley, B. K.: The amplitude and phasing of climate change during the last deglaciation in the Sulu Sea, western equatorial Pacific, Geophys. Res. Lett., 30, 1428, doi:10.1029/2002GL016612, 2003.
Shakun, J. D. and Carlson, A. E.: A global perspective on Last Glacial maximum to Holocene climate change, Quaternary Sci. Rev., 29, 1801-1816, 2010.

Shen, C.-C., Hasting, D. W., Lee, T., Chiu, C.-H., Lee, M.-Y., Wei, K.-Y., and Edwards, R. L.: High precision glacial-interglacial benthic foraminiferal $\mathrm{Sr} / \mathrm{Ca}$ records from the eastern equatorial Atlantic Ocean and Caribbean Sea, Earth Planet. Sci. Lett., 190, 197-209, 2001.

Shen, C.-C., Chiu, H.-Y., Chiang, H.-W., Chu, M.-F., Wei, K.-Y., Steinke, S., Chen, M.-T., Lin, Y.-S., and Lo, L.: High precision measurements of $\mathrm{Mg} / \mathrm{Ca}$ and $\mathrm{Sr} / \mathrm{Ca}$ ratios in carbonates by cold plasma inductively coupled plasma quadrupole mass spectrometry, Chem. Geol., 236, 339-349, 2007.

Shiau, L.-J., Chen, M.-T., Clemens, S. C., Huh, C.-A., Yamamoto, M., and Yokoyama, Y.: Warm pool hydrological and terrestrial variability near southern Papua New Guinea over the past 50k, Geophys. Res. Lett., 38, L00F01, doi:10.1029/2010GL045309, 2011.

Shiau, L.-J., Chen, M.-T., Huh, C.-A., Yamamoto, M., and Yokoyama, Y.: Insolation and cross-hemispheric controls on Australian monsoon variability over the past $180 \mathrm{ka}$ : New evidence from off shore southeastern Papua New Guinea, J. Quaternary Sci., 27, 911-920, 2012.

Steinke, S., Chiu, H.-I., Yu, P.-S., Shen, C.-C., Erlenkeuser, H., Löwemark, L., and Chen, M.-T.: On the influence of sea level and monsoon climate on the southern South China Sea freshwater budget over the past 22,000 years, Quaternary Sci. Rev., 25, 1475-1488, 2006.

Steinke, S., Kienast, M., Groeneveld, J., Lin, L.-C., Chen, M.-T., and Rendle-Bühring, R.: Proxy dependence of the temporal pattern of deglacial warming in the tropical South China Sea: toward resolving seasonality, Quaternary Sci. Rev., 27, 688-700, 2008.

Stenni, B., Jouzel, J., Masson-Delmotte, V., Röthlisberger, R., Castellano, E., Cattani, O., Falourd, S., Johnsen, S. J., Longinelli, A., Sachs, J. P., Selmo, E., Souchez, R., Steffensen, J. P., and Udisti, R.: A late-glacial high-resolution site and source temperature record derived from EPICA Dome $\mathrm{C}$ isotope records (East Antarctica), Earth Planet. Sci. Lett., 217, 183-195, 2003.

Stott, L., Poulsen, C., Lund, S., and Thunell, R.: Super ENSO and global climate oscillations at millennial time scales, Science, 297, 222-226, 2002.

Stott, L., Cannariato, K., Thunell, R., Haug, G. H., Koutavas, A., and Lund, S.: Decline of surface temperature and salinity in the western tropical Pacific Ocean in the Holocene epoch, Nature, 431, 56-59, 2004.

Stuiver, M., Reimer, P. J., and Reimer, R. W.: CALIB 6.0. (WWW program and documentation), available at: http://calib.qub.ac.uk/ calib/, 2010.

Visser, K., Thunell, R., and Stott, L.: Magnitude and timing of temperature change in the Indo-Pacific warm pool during deglaciation, Nature, 421, 152-155, 2003.

Wang, Y. J., Cheng, H., Edwards, R. L., An, Z. S., Wu, J. Y., Shen, C.-C., and Dorale, J. A.: A high-resolution absolute-dated late Pleistocene monsoon record from Hulu Cave, China, Science, 294, 2345-2348, 2001.

Wang, X., Auler, A. S., Edwards, R. L., Cheng, H., Ito, E., Wang, Y., Kong, X., and Solheid, M.: Millennial-scale precipitation changes in southern Brazil over the past 90,000 years, Geophys. Res. Lett., 34, L23701, doi:10.1029/2007GL031149, 2007. 
Waelbroeck, C., Labeyrie, L., Michel, E., Duplessy, J. C., McManus, J. F., Lambeck, K., Balbon, E., and Labracherie, M.: Sealevel and deep water temperature changes derived from benthic foraminifera isotopic records, Quaternary Sci. Rev., 21, 295-205, 2002.

Williams, A. P. and Funk, C.: A westward extension of the warm pool leads to a westward extension of the Walker circulation, drying eastern Africa, Clim. Dynam., 37, 2417-2435, 2011.

Xu, J., Holbourn, A., Kuhnt, W., Jian, Z., and Kawamura, H.: Changes in ther thermocline structure of the Indonesian outflow during Terminations I and II, Earth Planet. Sci. Lett., 273, 152$162,2008$.
Yan, X.-H., Ho, C.-R., Zheng, Q., and Klemas, V.: Temperature and size variabilities of the western Pacific warm pool, Science, 258, 1643-1645, 1992.

Zhao, M., Huang, C.-Y., Wang, C.-C., and Wei, G.: A millennialscale $U_{37}^{K^{\prime}}$ sea surface temperature record from the South China Sea $\left(8{ }^{\circ} \mathrm{N}\right)$ over the last $150 \mathrm{kyr}$ : Monsoon and sea-level influence, Palaeogeogr. Palaeoclimatol. Palaeoecol., 236, 39-55, 2006. 